\title{
OPETUKSEN JA TUTKIMUKSEN HYÖDYKKEISTÄMINEN
}

\author{
HEIKKI PATOMÄKI
}

$\mathrm{U}$ udet arviointijärjestelmät, uusi palkkajärjestelmä (UPJ) ja koko tulosjohtamisen ideologia perustuu pohjimmiltaan yksinkertaiseen ideaan. Lähtökohta on usko "vapaisiin markkinoihin" eli siihen, että vain markkinat pystyvät kohdentamaan voimavaroja tehokkaasti. Tästä uskosta seuraa vaatimus, että kaikkialle täytyy luoda markkinat, todelliset tai kuvitellut.

Jotta kouluihin, yliopistoihin tai esimerkiksi ministeriöihin voitaisiin rakentaa todelliset tai kuvitteelliset markkinat, täytyy toiminnasta ja sen tuloksista tehdä ensin hyödykkeitä. Hyödyke on tavara tai asia, jonka joku omistaa ja joka voidaan ostaa tai myydä markkinoilla. Siksi täytyy ensin hallinnollisesti määritellä, mitä ovat ne ”tavarat”, joita julkisorganisaatiot tuottavat. Esimerkiksi yliopistoissa tuotteiksi on määritelty opintosuoritukset, tutkinnot, tutkimukset ja asiantuntijapalvelut. Näitä lasketaan määrällisesti ja niitä arvioidaan laadullisesti monimutkaisten luokittelujen pohjalta.

Toiseksi täytyy määritellä yksityisomistajuus. Jonkun täytyy omistaa tuotantovälineet ja siten olla vastuussa tuotannosta. Niinpä jokaiselle työntekijälle, yksikölle ja toiminnalle nimetään tulosvastuullinen johtaja. Johtajien täytyy koko ajan suunnitella alaistensa toimintaa ja raportoida kaikesta sekä omille esimiehilleen että ulkoisille arvioitsijoille. Määrällisten tulosten ja laadullisten arvioiden perusteella määrätään - monimutkaisten laskennallisten kaavojen pohjalta - jokaiselle tulosvastuulliselle yksikölle vuosibudjetti, josta maksetaan myös ihmisten palkat. UPJ tarkoittaa puolestaan, että jokaisen työtekijän palkka määräytyy hänen vuosituotantonsa mukaan. Ei siis riitä, että kaikki toiminta ja sen tulokset on hyödykkeistetty, vaan jokaisesta yksilöstä tehdään urakkapalkkalainen. Palkkio työstä riippuu siis siitä, kuinka monta halkoa - määrämittaista tavaraa - kukin yksilö on kunakin vuonna saanut yksin pilkottua ja pinottua.

Järjestelmän suunnittelijat eivät näe, että mitä se, mitä he tekevät, saa aikaan. Yksi syy tähän on kapeakatseinen ideologisuus. Uuden järjestelmän luomisen pohjana ei ole minkäänlaista kokemusperäistä tietoa tällaisten kokeilujen vaikutuksista. Uusoikeistolainen usko "vapaiden markkinoiden” tehokkuuteen näyttää riittävän suunnittelun pohjaksi. Valtiovarainministeriön keskeiset virkamiehet ja pieni samanmielisten hallinnon tutkijoiden joukko käy keskusteluja vain keskenään. Kritiikkiä esittäneet yhteiskuntatieteilijät sivuutetaan olankohautuksella tai kuitataan vain yhtenä esimerkkinä "muutosvastarinnasta".

Syvemmällä tasolla kyse on myös käsitteistä. Järjestelmän suunnittelijat operoivat muutamalla yksinkertaisella käsitteellä ja vastakkainasettelulla, eivätkä kykene näkemään mitään muuta. Uusi on aina parempaa kuin vanha ja kaiken jatkuva "uudistaminen” on arvo sinänsä. Markkinat ovat aina parempi järjestely kuin byrokratia. Tehokkuus on ainoa olennainen arvo ja tuotannon tehokkuus täytyy pystyä mittaamaan. Työn tuot-

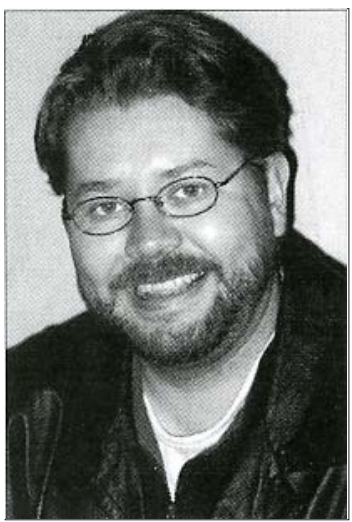

Heikki Palomäki tavuutta täytyy kyetä nostamaan myös valtionhallinnossa ja julkisissa organisaatioissa, jotta veroja voitaisiin alentaa, kansantuote kasvaisi ja Suomi säilyisi kilpailukykyisenä. Logiikka on niin vastaansanomaton, että oikeastaan mitään vaihtoehtoja ei näyttäisi olevan. Kapitalistinen markkinatalous on ainoa mahdollisuus ja sen periaatteet pitää saattaa voimaan kaikilla elämänalueille välittämättä niiden vastustuksesta, jotka eivät suostu ymmärtämään tai uskomaan ainoaa ja lopullista totuutta.

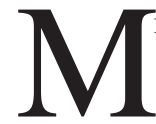
itä uuden järjestelmän todelliset vaikutukset sitten ovat? Nämä voidaan tiivistää kahteen aikaansaannokseen: yhtäältä uusi järjestelmä murentaa julkisorgani- 
saatioiden toiminnan moraalisen ja sosiaalisen perustan. Toisaalta se luo valtavasti lisää hallintoa. Uusi järjestelmä parantaa tehokkuutta vain sellaisen perverssin teorian mukaan, joka uskoo, että vain mitattu ja laskettu on todellista ja että työajan korvaukseton pidentäminen on "tehokkuuden” lisäämistä.

$\mathrm{F}$ lilosofit ja poliittisen talouden tutkijat tekevät erottelun sisäisen hyvän ja ulkoisen hyödykkeen välillä. Sisäinen hyvä seuraa asiasta tai prosessista itsestään. Usein yritys hyödykkeistää asia johtaa sen sisäisen arvon vähenemiseen. Omaa persoonallisuutta tai ystävyyttä tai rakkautta ei voi ostaa tuhoamatta tai turmelematta sitä. Lasten tai elinten tai seksin kauppa turmelee tai muuttaa merkityksiä. Monilla arkisilla tekemisillä tai käytännöillä itsessään on ihmisille arvoa ja merkitystä, jonka niiden hyödykkeistäminen turmelee. Kun opettaja saa opetettua lapsen lukemaan, molemmat osallistuvat sisäisen hyvän tuottamiseen, joka usein itsessään riittää toiminnan motivoimiseen. Kun sellisti oppii harjoittelun tuloksena soittamaan uuden vaikean kappaleen ja kykenee esittämään sen yleisölle, saa hän tyydytystä, joka on riippumatonta ulkoisista palkkioista. Kun tutkija keksii ratkaisun ongelmaan, joka on askarruttanut häntä ja hänen kollegoitaan vuosikausia, kokee hän täyttymyksen, jota mikään raha ei voi korvata.

Myös markkinat edellyttävät jaettuja moraalisia käsityksiä ja hienovaraisia sosiaalisia sääntöjä. Kapitalistisen markkinatalouden moraalinen perusta oli poliittisen talouden oppi-isille itsestään selvä asia. Esimerkiksi Kansojen varallisuuden 1776 julkaissut Adam Smith oli moraalifilosofi, ei taloustieteilijä sanan nykyisessä kapeassa ja teknisessä merkityksessä. Smithille ihmiset ovat sosiaalisia olentoja, jotka ovat aina riippuvaisia muista. Oma etu ei ole sen enempää tai vähempää luonnollinen motiivi kuin hyväntahtoisuus tai pyrkimys saada tunnustusta muilta ihmisiltä. Oman edun tavoitteluun perustuvat markkinat voivat toimia vain, jos markkinoita rajoitetaan ja säädellään sekä moraalisten että laillisten normien avulla. Myös taloudellinen toiminta tulee vaikeaksi ilman toimijoiden välistä luottamusta; kilpailun muotoja pitää säädellä (Smith oli suuryritysten ja monopolististen pyrkimysten jyrkkä vastustaja); ja esimerkiksi koulutus ja perusrakenteet pitää organisoida julkisesti, ilman markkinoiden logiikkaa.
On monia organisaatioita, joiden perusidea ja keskeiset käytännöt perustuvat sisäisen hyvän tuottamiseen ja joissa ihmisten toiminnan keskeisenä motiivina on muiden antaman tunnustuksen tavoittelu ja eettiset käsitykset tehtävistä ja velvollisuuksista. Myös tällaisten organisaatioiden sisältä löytyy itsekkyyttä, oman edun tavoittelua ja valtakamppailuja, mutta niiden luonne ja muoto voidaan ymmärtää ainoastaan suhteessa jaettuun moraaliseen ja sosiaaliseen perustaan. Kun toiminta ja sen tulokset hyödykkeistetään, murennetaan organisaatioiden moraalinen ja sosiaalinen perusta.

$\mathrm{H}$ yödykkeistäminen edellyttää myös raskaan ja monimutkaisen hallintokoneiston luomista ja uusien tulosvastuun ja johtamisen hierarkioiden luomista. Yhä suurempi osa työntekijöiden ajasta alkaa kulua tämän järjestelmän toiminnan pyörittämiseen. Työn luonne muuttuu. Aiemmin työstään spontaanisti innostuneet joutuvat tekemään ikäviä töitä, jotka koetaan ulkokohtaisiksi ja usein myös mielettömiksi suhteessa toiminnan varsinaiseen päämäärään. Insipiraatio, motivaatio ja työn mielekkyys katoaa, samalla kun työn määrä lisääntyy.

Mielettömyyden huipentaa kokemus vallattomuudesta. Aiemmin omassa vaikutuspiirissä olleet asiat on siirretty erilaisten ammattijohtajien päätettäviksi, jotka sitten palkitsevat itseään ”vaativasta työstä” ruhtinaallisilla palkkioilla. Tämä ei lisää tehokkuutta, vaan ainoastaan eriarvoisuutta, katkeruutta ja jopa vihaa.

Kirjoittaja on julkaissut kesäkuussa kirjan Yliopisto Oyj: Tulosjohtamisen ongelmat - ja vaihtoehto (Gaudeamus, 2005), joka käsittelee tämän kolumnin teemoja paljon yksityiskohtaisemmin. 